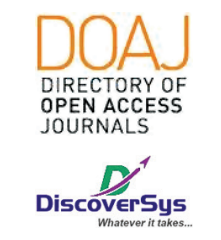

Published by DiscoverSys

\section{Red meat intake as a suspicious factor of colorectal cancer at Sanglah General Hospital in 2017}

\author{
Ganeshwary Nishal Ganasan, ${ }^{1 *}$ Made Agus Dwianthara Sueta, ${ }^{2}$ \\ Made Suka Adnyana²
}

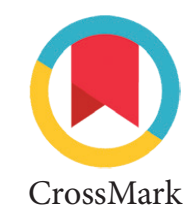

CrossMark

\section{ABSTRACT}

Background: Colon and rectal cancer (colorectal cancer) is cancer with high morbidity and mortality. Colorectal cancer is the second leading cause of death among men and women. This cancer is also the third most common malignant neoplasm in the world, and its incidence has increased in recent years. A high diet of red meat is one of the risk factors that can increase the likelihood of colorectal cancer.

Aim: The study aims to determine the relationship between red meat consumption on the incidence of colorectal cancer.

Method:This study is an unmatched paired case-control study conducted in Sanglah Hospital using patient medical record data from 2016 to 2017. The number of colorectal cancer group and control group samples are 52 people, each group. Samples were then interviewed on the red meat diet using the questionnaire guidelines. Data on the diagnosis of colorectal cancer was obtained through the patient's medical record at Digestive Surgery Polyclinic, Sanglah Hospital, Denpasar.

Result: About $76.9 \%$ of colorectal cancer patients consume a high intake of red meat. Patients with colorectal cancer have a history of higher red meat intake than patients without colorectal cancer $(0 R=$ 9.048; 95\% Cl 3.716-22.026; $\mathrm{p}<0.001)$.

Conclusion: Red meat intake is a significant factor in the incidence of colorectal cancer in Sanglah Hospital. Limiting the consumption of red meat is recommended to reduce the risk of colorectal cancer.
${ }^{1}$ Medical Science Study Program, Medical Faculty, Universitas Udayana

${ }^{2}$ Department of Surgery, Medical Faculty, Universitas Udayana, Sanglah General Hospital Denpasar Bali

*Corespondence to: Ganeshwary Nishal Ganasan, Medical Science Study Program, Medical Faculty, Universitas Udayana ganeshwarynishal@gmail.com

Received: 2018-06-28 Accepted: 2018-08-26 Published: 2019-08-01

Keywords: Colorectal cancer, red meat, risk factor

Cite This Article: Ganasan, G.N., Sueta, M.A.D., Adnyana, M.S. 2019. Red meat intake as a suspicious factor of colorectal cancer at Sanglah General Hospital in 2017. Intisari Sains Medis 10(2): 194-196. D0I: 10.15562/ism.v10i2.291

\section{INTRODUCTION}

Colorectal cancer is cancer with high morbidity and mortality rates. ${ }^{1}$ It is the second leading cause of death in men and women where the incidence rate has increased in recent years. ${ }^{2}$ According to the International Agency for Research on Cancer (IARC), there are about 550,000 new cases of colorectal cancer each year. ${ }^{2}$ The incidence of colorectal cancer in Asia is higher among certain ethnic groups, such as ethnic Malays, Indians, and Chinese. ${ }^{1,2}$ Previous research in Indonesia from 1996 to 1999 found its incidence rate was $35.2 \%$ in patients under 40 years old. ${ }^{3}$ Its prevalence in Bali, mainly in Sanglah General Hospital in 2009 until 2013 reached 97 patients. There were as many as $70.1 \%$ noted under 60 years old. The most common type of colorectal cancer is adenocarcinoma. ${ }^{4}$

The risk factors for colorectal cancer are varied in each country. These risks are also varied between individuals based on diet, lifestyle and genetic factors. ${ }^{2}$ Red meat intake is one of the risk factors that correlate strongly with the incidence of colorectal cancer. ${ }^{5}$ Appropriate mechanisms underlie the association between colorectal cancer risk and high intake of red meat still can not clearly explain. Furthermore, there is one study suggests that red meat has excessive fat, protein, and iron content. ${ }^{6}$ Excessive fat will stimulate bile secretion that acts as an aggressive surfactant in the colonic mucosa and will stimulate mucosal cell proliferation. In addition, fat triggers the occurrence of obesity which will lead to insulin resistance and related changes in the blood (high blood glucose levels, free fatty acids, insulin, and IGF-1); the circulating factors increase the proliferation and apoptosis of the pre-cancerous cells, thereby triggering tumor growth. ${ }^{6}$ According to a previous study, there was a strong association between colon cancer and the consumption of beef, pork, or mutton. The relative risk of colon cancer in this meat-eating population as a main course each day is 2.49 times greater than the population consuming less than once in one month (95\% confidence interval 1.24-5.03). ${ }^{5}$ It is beneficial to examine the association of red meat consumption and the incidence of colorectal cancer as a basis for prevention and education programs to the broader community.

\section{METHOD}

This is analytic research with unmatched paired control case design conducted at Sanglah Hospital, Denpasar from March to December 2017. The subjects were all colorectal cancer patients undergoing digestive surgical polyclinic therapy by using quota sampling technique at Sanglah Hospital in 2016. The inclusion criteria of case group subjects were all colorectal cancer patients undergoing 
treatment at Sanglah Hospital, while the control group was undiagnosed with colorectal cancer. Exclusion criteria were colorectal cancer patients who have a family history of colorectal cancer. The number of subjects in colorectal cancer group and control group was 52 persons. Research data is a combination of primary and secondary data. Primary data on the characteristics of red meat intake was obtained through interviews with interview guidelines in the form of questionnaires. While secondary data about the characteristics of colorectal cancer obtained through medical records of patients with digestive surgical polyclinic, Sanglah Hospital. Data were analyzed using the data processing program.

\section{RESULT}

The characteristics of obtained subjects are most fulfilled by the female $(62.50 \%)$ and the level of

Table 1 The characteristics of subjects $(n=104)$

\begin{tabular}{ll}
\hline Characteristics & $\mathbf{n}(\%)$ \\
\hline Gender & \\
$\quad$ Male & $39(37.50)$ \\
Female & $65(62.50)$ \\
Red Meat Intake (per day) & \\
$\quad$ High & $54(51.90)$ \\
Low & $50(48.10)$ \\
\hline
\end{tabular}

Table 2 Frequency distribution of red meat intake in colorectal cancer and non-colorectal cancer groups

\begin{tabular}{lcc}
\hline Red Meat Intake & $\begin{array}{c}\text { Colorectal Cancer Groups } \\
\mathbf{n}(\%)\end{array}$ & $\begin{array}{c}\text { Non-Colorectal Cancer } \\
\text { Groups } \mathbf{n}(\%)\end{array}$ \\
\hline High & $40(76.90 \%)$ & $14(26.90 \%)$ \\
Low & $12(23.10 \%)$ & $38(73.10 \%)$ \\
\hline
\end{tabular}

Table 3 The association of red meat intake and colorectal cancer incidence rate

\begin{tabular}{lccccc}
\hline Characteristics & $\begin{array}{c}\text { Case } \\
(\mathbf{n = 5 2})\end{array}$ & $\begin{array}{c}\text { Control } \\
(\mathbf{n}=\mathbf{5 2})\end{array}$ & $\mathbf{p}$ & OR & $\mathbf{C l} \mathbf{9 5 \%}$ \\
\hline $\begin{array}{l}\text { Red Meat Intake (per day) } \\
\quad \text { High }\end{array}$ & 40 & 14 & 0.000 & 9.05 & $3.72-22.03$ \\
$\quad$ Low & 12 & 38 & & & \\
\hline
\end{tabular}

Table 4 The association of gender and colorectal cancer incidence

\begin{tabular}{lccc}
\hline Characteristics & $\begin{array}{c}\text { Case } \\
(\mathbf{n = 5 2})\end{array}$ & $\begin{array}{c}\text { Control } \\
(\mathbf{n = 5 2})\end{array}$ & p-value \\
\hline Gender & & & \\
Male & 24 & 15 & 0.068 \\
Female & 28 & 37 & \\
\hline
\end{tabular}

consumption of red meat is high (51.90\%). The distribution of red meat intake frequency in the colorectal cancer group and non-colorectal cancer group was shown in Table 2. The results of this study indicated that most subjects with colorectal cancer consumed a high intake of red meat per day $(76.90 \%)$. While in other groups consume low intake of red meat per day (73.10\%).

The main data were analyzed to get the association of red meat intake and the incidence of colorectal cancer. The results of the analysis are shown in Table 3. The subjects with colorectal cancer having a history of high intake of red meat 9.05 times higher than the undiagnosed colorectal cancer groups. These results are statistically significant $(\mathrm{OR}=9.05$; 95\% CI 3.72-22.03; $\mathrm{p}<0.001)$. The association of gender and the incidence of colorectal cancer was also investigated in this study. The results of the analysis are shown in Table 4 . The results found that gender was not related to the incidence of colorectal cancer $(\mathrm{p}=0.068)$.

\section{DISCUSSION}

The results of this study indicate that subjects with colorectal cancer consumed more red meat compared. This result is consistent with several studies in several countries. Research in Takayama reported that there was a significant increase in risk for colorectal cancer in the group with a high intake of red meat per day. ${ }^{7}$ Meta-analysis research by 2015 stated that from 27 prospective cohort studies observed, there was an increased relative risk (RR) of colorectal cancer in the group who ate red meat (RR 1.11, 95\% CI: 1.03-1.119). ${ }^{8}$ Other studies in 2011 reported that there was an increased risk of colorectal cancer in the group eating red meat and processed meats as much as 140 grams per day. ${ }^{9}$ Other studies concluded that a high intake of red meat increased the incidence of colorectal cancer by $20 \%-30 \%{ }^{5}$

Several studies discussed a mechanism that could explain the relationship between red meat intake and colorectal cancer. Among them are the presence of $\mathrm{N}$-nitrous compound (NOC), heterocyclic amino, polycyclic aromatic hydrocarbon, heme in red meat, fat, unsaturated fatty acids, bile acids, and infectious agents. How to cook those red meats have an important role in causing the emergence of these compounds where those are carcinogenic. ${ }^{10}$ In addition, excessive iron intake in red meat plays a role in the incidence of colorectal cancer, where heme can cause oxidative damage and play a role in the formation of carcinogenic compounds $\mathrm{N}$-nitrous. ${ }^{11}$ 


\section{CONCLUSION}

Most of the subjects are female. More than half the total subjects with colorectal cancer consume red meat in large quantities each day. Red meat intake becomes a suspicious risk factor that plays a significant role in triggering the occurrence of colorectal cancer. Colorectal cancer group had a history of eating red meat 9.05 times higher than the group without colorectal cancer one.

Limitations of this study are the number of research subjects are few and not examined the minimal amount and type of red meat that can trigger the occurrence of colorectal cancer. So further research is needed by developing the limitations of this study.

\section{REFERENCES}

1. National Cancer Institute. Colorectal Cancer; 2015. [online] Available at: http://www.cancer.gov/types/colorectal. [Accessed on: 28 Juni 2017]

2. Al-Jashamy, K. Principle and practice of cancer prevention and control. Foster City: OMICS Group eBook; 2013. p.2.

3. Sudoyo, A., Hernowo, B., Krisnuhoni, E., Reksodiputro, A., dan Hardjodisastro, D. Colorectal cancer among young native Indonesians: A clinicopathological and molecular assessment on microsatelite instability. Med J Indones. $2010 ; 245$.
4. Vitriana, GK., Maliawan, S., dan Siki, KK. Karakteristik histologis, stadium klinis, dan terapi kanker kolon pada pasien lanjut usia di RSUP Sanglah. J Med Udayana; 2014

5. Aykan, N. Red meat and colorectal cancer. Rev Oncol. 2015; 9(1).

6. Aulawi, T. Hubungan konsumsi daging merah dan gaya hidup terhadap risiko kanker kolon. J Penelitian Sos Agama. 2013; 16(1).

7. Wada, K., Oba, S., Tsuji, M., dkk. Meat consumption and colorectal cancer risk in Japan: The Takayama study. Cancer Sci. 2017; 108(5): 1065-70.

8. Alexander, DD., Weed, DL., Miller, PE., Mohamed, MA. Red meat and colorectal cancer: a quantitative update on the state of the epidemiologic science. J Am Coll Nutr. 2015; 34: 521-43.

9. Chan, DSM., Lau, R., Aune, D., dkk. Red and processed meat and colorectal cancer incidence: meta-analysis of prospective studies. PloS One. 2011;6: e20456.

10. Samraj, AN., Pearce, OM., Laubli, H., dkk. A red mearderived glycan promotes inflammation and cancer progression. Proc Natl Acad Sci USA. 2015;112: 524-47.

11. Bastide, NM., Chenni, F., Audebert, M., dkk. A central role for heme iron in colon carcinogenesis associated with red meat intake. Cancer Res. 2015; 75: 870-9.

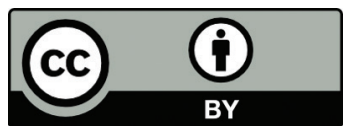

This work is licensed under a Creative Commons Attribution 